\title{
Unplanned Settlement Enclave Amidst Private City Developments
}

\author{
Edi Purwanto $^{1 *}$, Rachman Sjarief ${ }^{1}$, Anil Dawan ${ }^{1}$, Issa Samichat Ismail Tafridj ${ }^{2}$, Mochammad Veldian Ardana ${ }^{1}$, Dhini \\ Nur Oktiara ${ }^{1}$ \\ ${ }^{1}$ Department of Management \& Jaya Launch Pad, Universitas Pembangunan Jaya, South Tangerang 15413, Indonesia \\ ${ }^{2}$ Department of Architecture \& Center for Urban Studies, Universitas Pembangunan Jaya, South Tangerang 15413, Indonesia
}

Corresponding Author Email: edi.purwanto@upj.ac.id

https://doi.org/10.18280/ijsdp.160412

Received: 8 March 2021

Accepted: 2 July 2021

\section{Keywords:}

unplanned settlement, enclave settlement, urban residence, social capital, private cities

\begin{abstract}
The purpose of this research is to discover the factors which create the bonding social capital strengthening the relationship amongst Lengkong Kyai residents, Tangerang Regency, Banten, Indonesia. This research employs the qualitative method by triangulating primary data collected from in-depth interviews with local community leaders and public figures, field observation, and secondary data in the form of video recording, journalistic publications, and scientific journals from previous researches. The result shows that historical legacy, maintenance strategy, implantation of cultural, religious, and spiritual beliefs values, shared identity, as well as a relationship based on mutual trust are the factors contributing to the bonding social capital amongst Lengkong Kyai Residents. The novelty of this research is pointing out that policymakers, developers, even capitalist-oriented academicians often neglect the existence of bonding social capital in the development of urban settlements. This neglect often creates tension between kampong enclave's residents and housing developers. Coexisting and mutual respect becomes important in building bridging and linking social capital between kampong residents, housing developers, local government, and private city dwellers.
\end{abstract}

\section{INTRODUCTION}

The rapid urbanisation and migration rate to metropolitan such as Greater Jakarta has become an opportunity for real estate companies to develop housing in and around Jakarta. Real estate developers generated new cities in Greater Jakarta or more commonly known as Jabodetabek (Jakarta, Bogor, Depok, Tangerang, Bekasi), for example in the city of South Tangerang. New town or private city development is an escape from the high density of the metropolitan, aside from the intensifying and extensifying urban policies [1]. The spread of housing development also forms many private cities in and around Jakarta. Presently, there are at least 23 private cities in Greater Jakarta area [2].

There are several factors affecting the emergence of gated communities and private cities. These factors can be dichotomised into structural and individual factors. The structural factors are: (1) the increase of inequality and social polarity, (2) the influx of foreign investment and imitation of foreign styles, (3) the government withdrawing from providing various services, and (5) the high crime rate in the urban areas. The individual factors of gated community are (1) the increase of personal fear of crime, (2) individuals searching for better lifestyle (free from noise, pollution, and seeking privacy), (3) individuals searching for communities with similar socio-economical standing, (4) social homogeneity, (5) improved social status [2].

The widespread development of private cities requires a vast area or land, most of which are bought amicably from initial landowners. However, in several cases, a group of native residents may not be willing to sell their parcels of land, which results in the enclave settlement phenomenon where these collection of parcels of land are wedged in the middle of a large scale urban housing development [1]. Failing land deals with village residents, strong bonding social capital among neighbours and relatives, the longstanding heritage of history and identity are the factors preventing village residents from moving out of their homes, which eventually create kampong enclaves amidst the private city developments [1]. Ischak [1] call the kampong as native unplanned settlement and modern housing as new planned settlement.

Kampong enclave phenomena amidst private city and modern housing development, were internally created by the strength of social solidarity among the kampong residents, built on a long history of communality. This solidarity is a form of boding social capital [3]. This research aims to unearth the factors creating bonding social capital among kampong residents which safeguard the kampong settlement and its cultural heritage in Lengkong Kyai, South Tangerang.

\section{LITERATURE REVIEW}

\subsection{Kampong enclave}

The phenomenon of kampong enclave appeared when housing developers acquiesced large scale of land to create new town and planned settlements. Several kampong or villages which have existed for generations may collectively reject the land acquisition process. When the other parcels 
around their kampong have been acquiesced by the developers, their kampong are then become enclaved amidst luxurious housing developments. For security, comfort, and luxury rationales, real estate developers create tall fences and elaborate entry gates to control the movements of people and goods in and out of the housing developments. The gates and fences caused the native kampong to be excluded by and isolated from the surrounding high class housing developments [4].

According to Tanumihardja [4] there are many kampong enclaves alongside Cisadane River Bank in Greater Tangerang which require more innovation than mere housing renovation programmes. Cohesion formed between the kampong and real estate developers is also imperative, as in the status quo, the existence of the kampong enclaves is overlooked by the developers causing this very issue at the first place.

Pangaribuan and Haryanto [5] described kampong enclaves as urban villages wedged in a middle of skyscrapers. The development of buildings like hotels, apartments, and shopping centres adds a perspective of inequality among kampong enclaves and the new development around them. Land requirements for development are consuming lands owned by local residents and possess a threat of eviction towards kampong enclaves' dwellers.

Kampong enclave phenomenon is not specific to Indonesia, but it also exists in various Asian countries. Douglass et al. [6] discovered that new urban developments by real estate companies in China also resulted in enclaved areas. The emergence of luxury housing clusters also encourages segregation and inequality between residents of the housing clusters and kampong dwellers.

Breitung [7] also found that urban housing developments appear in many regions in China, making enclaves residential a fundamental characteristics from the spatial structure of Chinese urban areas. Breitung [7] also discovered that there is a strong will from housing residents to separate themselves with those residing beyond the cluster borders. Residents of the modern housing developments regard walls and gates as a high-level security measure, symbolic statement of status, and a product of a good life. This gated housing development often triggers social tension between housing residents and those living outside of it.

Tedong et al. [8] reported that this real estate phenomenon also grew in Malaysia. Although the development of gated communities guarantees safety and comfort, this system also reinforces and produces inequality among classes and ethnicities in Malaysian urban areas.

Medtry et al. [9] suggested that tourism development in kampong enclaves is possible. Although this suggestion heavily focused on river tourism and local culinary, the case study of Medtry's research hosts an important religious and cultural site that can be developed into a religious and cultural tourism attraction.

\subsection{Social capital}

In the last two decades, the concept of social capital has been an increasing centre of attention for scholars in various social sciences [10]. Bordieu perceived social capital as an affiliation into a social class or a certain group of people [11]. Putnam argued that the social capital referred to the relationship among individuals, which are social networks and the norms of returning favours, as well as the beliefs system which was conceived among them [10]. Furthermore, according to Coleman, social capital is real or potential resources attained through interwoven relationships. Norms, beliefs, punishments, and shared value become critical in maintaining this collective asset [10]. In the contemporary definition, the term "social capital" is linked to norms and cooperative networks, reciprocity, and relations based on beliefs, which has only been studied after the twentieth century [10].

The social capital itself has three dimensions, which are bridging, bonding, and linking social capital $[10,11]$. Bonding social capital refers to the strong ties already constructed within a community. Bridging social capital is the network or relation constructed among communities. Each individual in each respective community develops trust and reciprocity, not only among their own community but also with individuals from the other communities linked by the bridging social capital. Meanwhile, linking social capital connects social groups where those in power can distribute access to resources for all individuals in the linked groups. The difference between this dimension and the others is that linking social capital represents a vertical relationship, while bonding and bridging social capital represent horizontal relationships [10].

\subsection{Bonding social capital}

Bonding social capital can be defined as the source and beliefs already installed in the relationship among individuals, which can be accessed and mobilized by every member to select individual or shared goals [12].

In a religion-based community, according to Robbins et al. [13] bonding social capital can be formed when one experiences a feeling of loved and cared for by other members of the community, able to share personal issues and strive to lighten the load, able to share various religious experience, aided by their surrounding environment to live according to their shared religion, and helped in knowing God better.

In the context of a low-income community, Brisson \& Usher [14] suggested that bonding social capital is the resource embedded in the relationship of trust among neighbours in one community. There is an economic virtue in bonding social capital, where when members of the same community help each other and lighten the load. One financially struggling member of the community will be held up by their neighbours and this favour will be reciprocated in the future.

\subsection{Research gaps}

Previous studies about the settlements enclave amidst modern housing, or in Indonesia case, enclaved kampong surrounded by modern private cities, focuses more on the primordial conflict between the residents of the squeezed village (kampong) and the residents of modern housing.

Previous studies did not explore why the residents of the squeezed village did not want to accept the presence of a modern private city and were not willing to sell their land to become part of a private city. Previous studies did not dig deeper into why they maintained their village, which was squeezed and surrounded by modern urban housing, even surrounded by walls built by modern city developers.

Since most of the researchers in previous studies mainly had an architectural background, these researchers did not try to explore the existence of bonding social capital, which is the glue that binds the villagers to defend their village from the acquisition of modern private housing developers. 
This study explores the existence of bonding social capital among the residents of Lengkong Kyai village and looks for factors that shape the strength of their bonding social capital. Their strong bonding social capital is hypothesized as a motivating factor for them to defend their village from the acquisition of modern housing developers, even though their village is finally sandwiched between or surrounded by modern housing walls.

\section{METHOD}

This research will apply the use of the qualitative case study method. The location of this research is in Kampong Enclave Lengkong Kyai or Lengkong Ulama, RW 01, Lengkong Kulon village, Pagedangan Sub-district, Tangerang Regency. Figure 3 is the map of Lengkong Kyai Kampong. The population of Lengkong Ulama (RW 01) is 1500, divided into three different RTs: 608 in RT 01 with total area of 4.28 ha; 448 in RT 02 with total area of $4.99 \mathrm{ha}$; and 444 in RT 03 with total area of 1.52 ha $[9,15]$. This area is surrounded by the luxury housing of a private city, BSD City (see Figure 1).

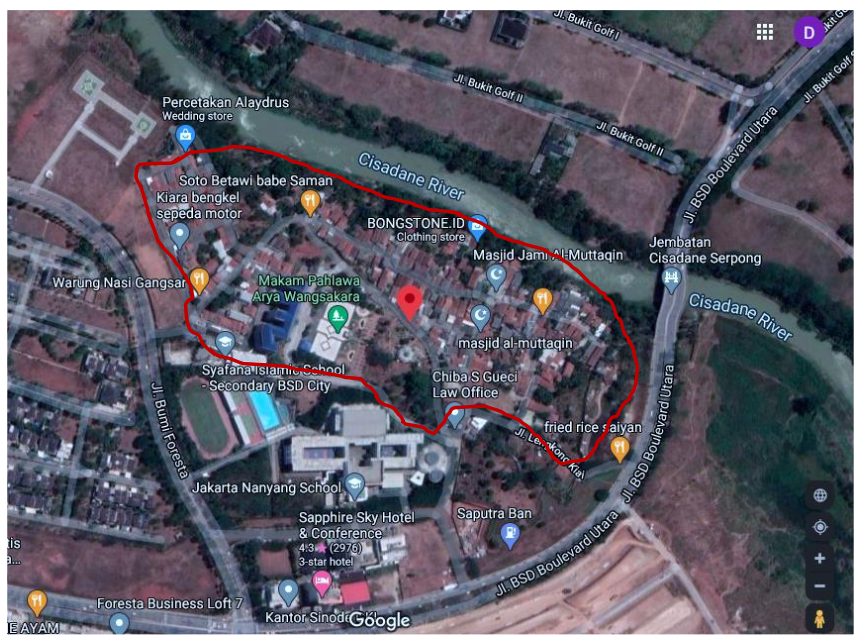

Figure 1. Lengkong Kyai area

The data employed in this research is collected through indepth interviews. According to Colaizzi [16], the number of informants depends largely on the amount of factors tested in each research project. In this case, in-depth interviews were conducted with a local public figure. The head of each respective RT, public figures of cultural significance (Babad Banten Nusantara and Balai Adat Keriaan Tangerang), head of the youth organization, and some other unstructured interviewed. In addition to the interviews, field observation was also conducted in several opportunities.

Aside of the aforementioned primary data, secondary data was also collected. These are 1) Video recording on YouTube platform of preaching religious leaders discussing the history and lineage of Lengkong Kyai, 2) Journalistic articles discussing Lengkong Kyai, and 3) Papers and journals reviewing Lengkong Kyai.

These data were then triangulated, which is a collection of data from different sources with a similar degree of relevancy to the phenomena in question [17]. The triangulation method is a long process that leads to data saturation through various data sources [17]. Triangulation guarantees that these data are resourceful and profound $[18,19]$.

According to Ihalauw [20], case study research must end with the formation of propositions into mini-theory. These concepts are linked based on reasoning and possibly existing theories to become propositions and eventually form a theory. And according to Jonker and Pennink in [19], a mini theory is a theory that applies to a particular situation and still needs to be proven its general validity through retesting the mini theory with the application of quantitative research.

\section{RESULT}

This research discovered several factors which creates the bonding social capital in Lengkong Kyai. The formation of social capital, especially bonding social capital within the community in this kampong enclaved amidst luxurious housing developments, are driven by the following factors.

\subsection{Historical heritage}

The emergence of kampong enclaves in Tangerang was caused in one hand by the endemic luxury housing development and the expansion of private cities built by large scale developers. On the other hand, kampong residents, who have settled in the area much longer, are not willing to sell their land parcels. Because developers have bought the vast area of land surrounding their kampong for that new housing development, naturally, their kampong is stuck between luxury housing clusters. They refuse to sell their parcels and their houses because their families have lived there for generations. A strong attachment has been formed between the kampong resident and their kampong [1].

Residents of the kampong enclaves in Lengkong Kyai believe that their families and ancestors have been settling in the kampong for centuries. They believe that Raden Aria Wngsakara first started Lengkong Kyai in the 1600s, and the residents of Lengkong Kyai are all direct descendants of his [21]. Citizens settling in Lengkong Kyai believe that Raden Aria Wangsakara, whose grave has been appointed as a heritage site by Tangerang Regency government, is their ancestor. The entry gate into this heritage site bears a sign "Raden Aria Wangsakara's Heroes Cemetery" (see Figure 2 and Figure 3).

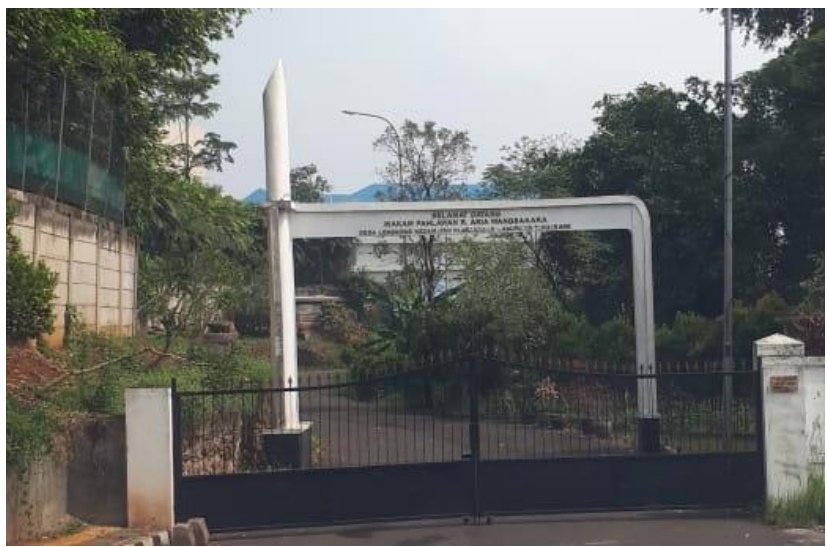

Figure 2. Gate of aria Wangsakara's heroes cemetery

Besides being known as an Islamic propagator, Raden Aria Wangsakara was also known as a hero in the fight against Dutch colonialization. He raised the morale of Tangerang citizens to fight against the Dutch' attacks on the Banten Empire. He also established a settlement for war victims and 
initiated an Islamic education institution (pesantren) in Lengkong Kyai [21]. According to the tale, after the pesantren in Grendeng, Karawaci, was attacked by the Dutch, Raden Aria Wangsakara built settlements and pesantren in the area we now identify as Lengkong Kyai [22].

Raden Aria Wangsakara was also considered one of the founders of Tangerang. In recent years, Tangerang's historic anniversary was amended from $27^{\text {th }}$ December 1943 to $13^{\text {th }}$ October 1632, partly due to a handwritten manuscript owned by the descendants of Raden Aria Wangsakara [23].

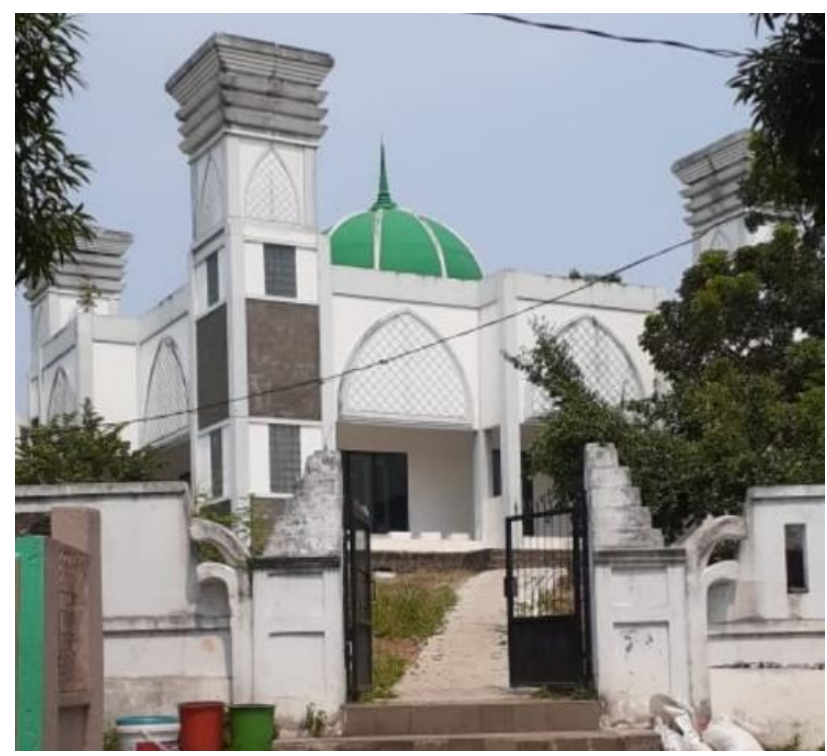

Figure 3. Aria Wangsakara's heroes cemetery

Due to this belief that they are the descendants of the founder of Tangerang, not merely the founder of Lengkong Kyai, the people's attachment to centuries, old Lengkong Kyai becomes stronger. This kampong is no longer only a place in which they live, but it is also an affirmation of their identity as the descendants of Raden Aria Wangsakara.

Lutfi Abdul Gani and Mukhlis described that more than 70 percent of Lengkong Kyai are descendants of Raden Aria Wangsakara, a claim that community leaders corroborated. Mr. Jaro, a local public figure, further confirms this statement during an interview (interview 17/12/2020).

Local leaders explain that most of the villagers are descendants of Prince Aria Wangsakara. He is the founder of Lengkong Kyai village. So, in terms of the cultural context, the Lengkong Kyai village is their identity as descendants of Prince Aria Wangsakara [15]. Kyai is Ulama, and Ulama is Scholar in Islam science, and it is also referring to scholars of Islamic Jurisprudence. Lengkong Kyai refer to village or settlements of Ulama. The Ulama is Raden Aria Wangsakara and his descendants. So when dwellers defend the village, it is because the Lengkong Kyai is no longer only a place in which they live, but it is also an affirmation of their identity as the descendants of Raden Aria Wangsakara.

Chandra and Pramukanto [24] To maintain historical values from the threat of modern city development, the basic concept of future planning is to make Kampung Lengkong Kyai a village with a solid and sustainable identity of cultural landscape characteristics through conservation actions. Aryanto [25] also report that in order not to lose their identity, the villagers of Lengkong Kulon Village also maintain their local culture and wisdom. So this kampong is both their residents and identity.
4.2 Maintaining and instilling cultural values by customary institutions

Babad Banten Nusantara and Balai Adat Keariaan Tangerang are Customary institutions related this kampong. Lutfi Abdul Gani from Babad Banten Nusantara and Mukhlis from Balai Adat Keariaan Tangerang explained that the aligning of Raden Aria Wangsakara's lineage was appointed to Babad Banten Nusantara. Babad Banten Nusantara is an institution initiated and managed by the descendants of Raden Aria Wangsakara. To maintain cultural sustainability, Babad Banten Nusantara instigated Balai Adat Keariaan Tangerang (interview 17/12/2020).

In the ceremony to handover Lengkong Kyai Pedigree to Bunyamin Davnie, who was South Tangerang Vice Mayor, Lutfi Abdul Gani stated that there were now Badan Kekancingan Babad Banten and Balai Adat Keariaan Tangerang which were given the responsibility to record and maintain the ancestral culture, especially in Tangerang or other areas related to Banten Sultanate [26].

Mukhlis further elaborated that as one of the administrators of Balai Adat Keariaan Tangerang, he conducted programmes to instill cultural heritage values to the young generation in order to maintain the continuity of these values. According to Mukhlis, the local community leaders, religious leaders, and youth organizations in Lengkong Kyai have also been actively contributing to the maintaining and instilling of cultural heritage values or as they liked to call, "ke-Aria-an", or Arianess, taken from Raden Aria Wangsakara's name (Interview 17/12/2020).

According to Mukhlis, the youth in the area have been directed to create a youth organisation programme to help transform Raden Aria Wangsakara's cemetery site as a cultural tourism attraction and prepare the youths to be the tour guides in exploring Lengkong Kulon. This program will cover not only the cemetery site, but also the calligraphy museum, Cisadane river tourism, and Lengkong's special culinary tour (Interview 17/12/2020).

The search for Raden Aria Wangsakara's pedigree by Babad Banten Nusantara and the maintenance of Aria-related cultural values along with their instilment to the young generation will sustain the bonding social capital among the citizens. This bonding is not only in the sense of familial relationship as the descendants of Raden Aria Wangsakara, but it is also a bond with Lengkong kampong, which is considered their sacred homeland by many.

Lutfi Abdul Gani and Mukhlis explained that they wished the cultural heritage appointment to Raden Aria Wangsakara's legacy was not limited to his Heroes Cemetery but also to Lengkong Kyai kampong. This is due to the inseparable bond among the cemetery, the kampong, and the people. Their shared identity as the descendants of Raden Aria was strengthened by the bond with the cemetery and the kampong (interview 17/12/2020).

\subsection{Religion or shared religious beliefs}

Raden Aria Wangsakara, other than a national independence hero, is also a religious propagator, he was involved in the spread of Islam in Java [22]. His personality as religious leaders is a highly regarded pride for his descendants - Lengkong Kyai residents, who are pious Muslims. Lengkong Kyai kampong was not only established as settlement but was also a pesantren, a center of Islamic education for the people. To call Lengkong Kyai an Islamic kampong is considered a 
proper identification. As suggested by Robbins et al. [13], similar faiths and beliefs can contribute to the formation of a robust social capital. The various religious experience and assistance in learning the religion or understanding Allah helped formulate the bonding social capital [13].

There are many ways to connect religion and social capital, and there are various different aspects of religion which are related to social capital. Several researchers had proven the connection between religiousness and social capital. The solidarity formed within the communality of prayers creates a robust social capital among the members of certain religion [27]. In this case, the solidarity as a community who are descendants of a famous religious leader, Raden Aria Wangsakara, creates a strong bonding social capital among Lengkong Kyai residents.

\subsection{Shared identity}

Shared identity is a factor in strengthening bonding social capital [12]. Most of Lengkong Kyai's residents are descendants of Raden Aria Wangsakara. They have this shared identity as the initiator of the kampong. This shared identity strengthens the bonding social capital among them. As Robbins et al. [13] argued, a robust bonding social capital is more likely to be borne out of feeling types as opposed to thinking types. Shared identity as the descendants of a highly respected religious leader cultivates a strong feeling of attachment as one big family.

During the field observation, when informants would run into one of the residents, they would immediately introduce them as a descendant of Raden Aria. Upon descending from the cemetery, the informants led us to a small coffee shop named KKL (Kedai Kopi Lengkong or Lengkong Coffee Shop), and they also quickly informed us that the owner of the coffee shop was Raden Aria's descendant (see Figure 4). Later on, some public figures would join us in the coffee shop, and the same introduction would happen. Nearly all residents of Lengkong Kyai were introduced as descendants of Raden Aria Wangsakara. This belief and pride of their descendant status tie into their shared feeling of fraternity. This shared identity is a strengthening factor of Lengkong Kyai residents' bonding social capital.

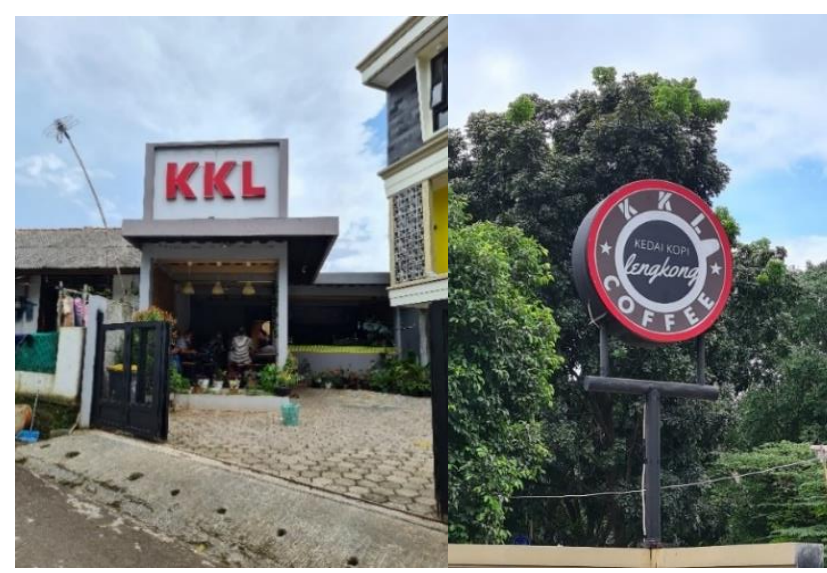

Figure 4. Lengkong cofee shoop

\subsection{Bond of trust}

According to Brisson and Usher [14], collective efficacy unifies the concepts of social cohesion, trust, and social control, whereas bonding social capital unifies the concept of social cohesion and trust. Jhang [12] also explained that the trust relationship is the determining factor in the creation of bonding social capital. Repeated and increased interaction among members of society enables the mutual feeling of trust and expectation of reciprocity from one another. Collective assistance and the demands of good conscience of reciprocity will create a strong bond of trust among members of the community Jhang [12]

The limited access to resources beyond the community compounded by the internal ecosystem of helping each other will further strengthen the bonding social capital because these experiences have instill a collective trust among members of the society [10]. When individuals in the community feel loved and cared for by other members, and they feel as though they can share their problems and solve issues together, a robust bond of trust and bonding social capital can be formed [13].

Long-term co-living can also create bonding social capital [10]. Because Lengkong Kyai Residents are native to the kampong, they have not only lived together for a long time, but they also believe that their ancestors have settled in the area since centuries ago. Therefore, although modern urban life keeps flourishing around them, particularly from the development of the private city which has surrounded their kampong, the bonding social capital based on a bond of trust among members of the community compels them to persevere and guard their kampong along with their ancestral values which were believed to be their shared identity.

Kampong is often defined as a vernacular housing settlement that displays rural characteristics and traditional lifestyle, which are imperative to the resilience of their community. Kampong displays a high level of solidarity and social interaction among its residents. Based on the vernacular character and the bonding social capital, houses in kampong are often built manually by the residents [3].

The characteristic of Lengkong Kyai residents' lifestyle is distinct from the lifestyle of the individualistic private city residents. Village or rural lifestyle is more pronounced in Lengkong Kyai, and therefore the high level of solidarity and intensive social interaction creates a bond of trust among the residents, which then strengthen the bonding social capital. As Brisson \& Usher [14] stated, bonding social capital is a resource embedded in the relationship of mutual trust among neighbours

\subsection{Proposed theory}

Based on the analysis above, several concepts emerged: historical heritage, cultural values, religious beliefs, shared identity, and bonding trusts. The concepts are forming the bonding social capital of the villagers of Lengkong Kyai. Then these concepts can be built into propositions that are strengthened by existing theories or studies.

Murzyn-Kupisz and Działek [28] historical heritage, cultural value, share value or identity, and trust have an impact on social capital. Maselko et al. [29] indicate the religious, values and norms, bonding trust form the bonding social capital. Han et al. [30] found the relationship between cultural values and social capital. Smidt [31] wrote religion as social capital. Furbey et al. [32] wrote faith as social capital. Park and Bowman [33] indicate the religious beliefs as bonding social capital. Auguste [34] found the relationship between exclusive religious beliefs and bonding social capital. 
Based on the discussion above, the propositions that form a model or theory is proposed as the Figure 5:

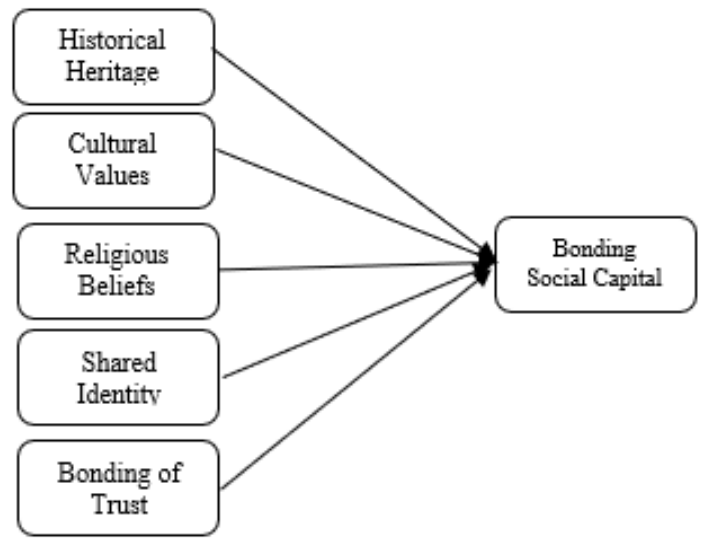

Figure 5. Proposed theory

\section{CONCLUSIONS}

The conclusion of this research is that historical heritage is the main factor contributing to the development of bonding social capital, as well as the strategy of maintaining and instilling cultural values, religion or shared beliefs, and shared identity. The attachment of beliefs which was built from decades of living together and interacting within a community coming from one ancestor and submitting to one belief system, is also a critical factor in contributing to the formation of bonding social capital among Lengkong Kyai residents.

Research Limitation: the limitation of this research is that it only highlights the existence of bonding social capital and the factors of its conception among the residents of Lengkong Kyai, Tangerang Regency. Matters related to the economic potentials from this social capital have not been studied further. Bridging social capital that channels the harmonious relationship with BSD City residents - a luxurious housing development - has also not been studied.

Future research: Based on the limitation, it is important first to conduct research that studies the economic potentials of the bonding social capital among the people. Second, future research is required to understand the bridging further and linking social capital, which links to the harmonious relationship between kampong residents and the residents of BSD City, along with the local government.

\section{ACKNOWLEDGMENT}

This research is funded by the research grant of the Center for Research and Community Service (LPPM) Universitas Pembangunan Jaya, Indonesia. The Research grant funds under the contract with LPPM No: 001/PER-P2M/UPJ/11.20. Wednesday, November 25, 2020.

\section{REFERENCES}

[1] Ischak, M., Setioko, B., Nurgandarum, D. (2018). Socio spatial adaptation as a resilience form of native unplanned settlement in confrontation with new planned settlement development pressure (case study: Enclave native settlement in Serpong, Tangerang). IOP Conf. Ser.
Earth Environ. Sci., 99(1). https://doi.org/10.1088/17551315/99/1/012009

[2] Kassim, N., Abdullah, N.A. (2010). The effect of perceived service quality dimensions on customer satisfaction, trust, and loyalty in e-commerce settings: A cross cultural analysis. Asia Pacific J. Mark. Logist., 22(3): https://doi.org/10.1108/13555851011062269

[3] Shirleyana, S., Hawken, S., Sunindijo, R.Y. (2018). City of Kampung: risk and resilience in the urban communities of Surabaya, Indonesia. Int. J. Build. Pathol. Adapt., 36(5): 543-568. https://doi.org/10.1108/IJBPA02-2018-0025

[4] Tanumihardja, D.S. (2018). The role of higher education institution in addressing 'Kampung Terjepit; phenomenon along cisadane riverbanks in Tangerang region. J. AGORA, 16(2): 69-75.

[5] Pangaribuan, B., Haryanto, R. (2019). Kajian penerapan konsep TDR skema kompensasi non finansial pada kawasan kumuh di kelurahan sekayu. J. Pembang. Wil. dan Kota, 15(2): 108-121. https://doi.org/10.14710/pwk.v15i2.21435

[6] Douglass, M., Wissink, B., van Kempen, R. (2012). Enclave urbanism in china: consequences and interpretations. Urban Geogr., 33(2): 167-182. https://doi.org/10.2747/0272-3638.33.2.167

[7] Breitung, W. (2012). Enclave urbanism in China: Attitudes towards gated communities in Guangzhou. Urban Geogr., 33(2): 278-294. https://doi.org/10.2747/0272-3638.33.2.278

[8] Tedong, P.A., Grant, J.L., Wan Abd Aziz, W.N.A., Ahmad, F., Hanif, N.R. (2014). Guarding the neighbourhood: The new landscape of control in Malaysia. Hous. Stud., 29(8): 1005-1027. https://doi.org/10.1080/02673037.2014.923089

[9] Medtry, Haryo, B., Madjid, K. (2016). Kajian Penataan Eksistensi Ampung Terjepit (Enclave) Akibat Pengembangan Perumahan Skala Besar (Studi Kasus Kampung Lengkong Ulama Desa Lengkong Kulon, Kecamatan Pagedangan, Kabupaten Tangerang). http://digilib.mercubuana.ac.id/manager/t!@file_artikel _abstrak/Isi_Artikel_913165231362.pdf.

[10] Andriani, L., Christoforou, A. (2016). Social capital: A roadmap of theoretical and empirical contributions and limitations. J. Econ. Issues, 50(1): 4-22. https://doi.org/10.1080/00213624.2016.1147296

[11] Ahn, J. (2012). Teenagers' experiences with social network sites: Relationships to bridging and bonding social capital. Inf. Soc., 28(2): 99-109. https://doi.org/10.1080/01972243.2011.649394

[12] Jhang, F.H. (2019). Bonding social capital and political trust: The mediating role of trust in public figures in Taiwan. Soc. Sci. https://doi.org/10.1016/j.soscij.2019.07.009

[13] Robbins, M., Francis, L.J., Powell, R. (2012). Congregational bonding social capital and psychological type: An empirical enquiry among Australian churchgoers. Ment. Heal. Relig. Cult., 15(10): 10091022. https://doi.org/10.1080/13674676.2012.676264

[14] Brisson, D., Usher, C.L. (2007). Conceptualizing and measuring bonding social capital in low-income neighborhoods. J. Soc. Serv. Res., 34(1): 1-11. https://doi.org/10.1300/J079v34n01_01

[15] Purwanto, E., Sjarief, R., Dawan, A., Tannady, H. (2020). 
The heritage tourism development as the sustainable development goal of the enclave settlement: A preliminary research. IOP Conf. Ser. Mater. Sci. Eng., 990(1): $\quad 8-12$. https://doi.org/10.1088/1757899X/990/1/012010

[16] Colaizzi, P.F. (1987). Psychological research as the phenomenologist views it. Existential Phenomenological Alternatives for Psychology, New York, NY: Oxford University Press, pp. 48-71.

[17] Locke, K.D. (2011). Grounded Theory in Management Research. London: SAGE Publications.

[18] Fusch, P.I., Ness, L.R. (2015). Are we there yet? Data saturation in qualitative research. Qual. Rep., 20(9): 1408-1416.

[19] Purwanto, E., Kameo, D.D., Joi Ihalauw, J., Priyanto, S.H. (2017). The complexity of poverty among Benteng Chinese in Tangerang District, Indonesia. J. Appl. Econ. Sci., 12(3): 820-831.

[20] Ihalauw, J.J. (2016). Dari Realitas Bisnis Ke Teori Mini. Jakarta: Tisara Grafika.

[21] Gani, L.A. (2020). Ki Leluhur: Rekam Jejak Sejarah Raden Aria Wangsakara. Yogyakarta: Deepublish.

[22] Iqbal, M. (2020). Aria Wangsakara, Ulama Pejuang Pendiri Wilayah Tangerang. IDN Times.

[23] Irawan, C. (2019). Berkat Sebuah Manuskrip, Hari Jadi Kabupaten Tangerang Diubah. IDN Times.

[24] Chandra, R., Pramukanto, Q. (2016). Perencanaan Lanskap Untuk Pelestarian Kawasan Budaya Kampung Lengkong Kyai, Tangerang. http://repository.ipb.ac.id/handle/123456789/80792.

[25] Aryanto, A. (2018). Semangat eksistensi kampung lengkong Kulon. Warta Ekonomi.

[26] TMS. (2019). Keluarga Besar Lengkong Berikan Silsilah kepada Bunyamin Davnie. Suara Keadilan. https://suarakeadilan.id/3267/keluarga-besar-lengkongberikan/.

[27] Kaasa, A. (2013). Religion and social capital: evidence from European countries. Int. Rev. Sociol., 23(3): 578596. https://doi.org/10.1080/03906701.2013.856162

[28] Murzyn-Kupisz, M., Działek, J. (2013). Cultural heritage in building and enhancing social capital. J. Cult. Herit. Manag. Sustain. Dev., 3(1): 35-54. https://doi.org/10.1108/20441261311317392

[29] Maselko, J., Hughes, C., Cheney, R. (2011). Religious social capital: Its measurement and utility in the study of the social determinants of health. Soc. Sci. Med., 73(5): $759-767$. https://doi.org/10.1016/j.socscimed.2011.06.019

[30] Han, J., Lee, H., Hovav, A. (2016). The effect of individual's cultural values and social capital on knowledge sharing in web-based communication environment. J. Mod. Proj. Manag., 4(2): 110-119. https://doi.org/10.19255/JMPM01111

[31] Smidt, C.E. (2003). Religion as Social Capital: Producing the Common Good. Texas: Baylor University Press.

[32] Furbey, R., Dinham, A., Farnell, R., Finneron, D., Wilkinson, G. (2006). Faith as social capital: Connecting or dividing? York: Joseph Rowntree Foundation.

[33] Park, J.J., Bowman, N.A. (2015). Religion as bridging or bonding social capital: Race, religion, and cross-racial interaction for college students. Sociol. Educ., 88(1): 2037. https://doi.org/10.1177/0038040714560172

[34] Auguste, D. (2019). Exclusive religious beliefs and social capital: unpacking nuances in the relationship between religion and social capital formation. Issues Race Soc. An Interdiscip. Glob. J., 57-84. 